\title{
Predictions of Financial Distress in Consumption Goods Industrial Companies Listed on the Indonesia Stock Exchange in 2016-2018
}

\author{
Muhammad Khusni Mubarrok ${ }^{\mathrm{a}^{*},}$, Mohammad Wasil ${ }^{\mathrm{b}}$, I.G.A. Aju Nitya Dharmani ${ }^{\mathrm{c}}$ \\ ${ }^{a}$ Faculty of Economics anda Business, Narotama University Surabaya, Indonesia, mubarrokkhusni@gmail.com \\ ${ }^{b}$ Faculty of Economics anda Business, Narotama University Surabaya, Indonesia, wasilunnar@gmail.com \\ ${ }^{c}$ Faculty of Economics anda Business, Narotama University Surabaya, Indonesia, ayurai.management@gmail.com
}

\begin{abstract}
This study aims to determine the prediction of financial distress in the Consumer Goods Industry companies listed on the Indonesia Stock Exchange. The research period used was 2016-2018. This research on financial distress prediction uses a quantitative approach. The study population includes all Consumer Goods Industry companies listed on the Indonesia Stock Exchange in the 2016-2018 period. The sample is determined by purposive sampling technique. The data analysis method used is logistic regression analysis. This study aims to test and prove whether DAR, CR, TATO, and ROA affect the Financial Distress. The data in this study came from secondary data obtained through documentation techniques. Data analysis by logistic regression partially used SPSS for window version 25 . The results showed that (1) Debt Asset To Ratio (DAR) had no positive effect on Financial Distress. (2) Current Ratio (CR) has a negative but not significant effect on Financial Distress. (3) Total Asset Turnover (TATO) has no negative effect on Financial Distress. (4) Return on Assets (ROA) has a negative and significant effect on Financial Distress.
\end{abstract}

Keywords : Debt Asset To Ratio (DAR), Current Ratio (CR), Total Asset Turnover (TATO), Return On Asset (ROA, dan Financial Distress.

\section{Introduction}

According to Hidayat and Meiranto (2014) "The development of the world economy in recent years has experienced very rapid progress. This rapid progress is due to the increasingly strong and widespread globalization throughout the world. A strong and experienced business will increasingly benefit from the widespread influence of globalization. Mirae Asset, (2018) "Indonesian securities in a research published on Friday (10/19/2018), assessed that the growth of the consumer goods industry in Indonesia is experiencing a slowdown in recent years.

According to Pranowo et al. (2010) "In the development of globalization, there are several adverse impacts that can be felt, one of which is the global financial crisis in 2008 which resulted in the weakening of business activity in general. Most countries around the world experienced financial setbacks and disasters due to the outbreak of the financial crisis. Increasing market competition makes it more difficult for a company to maintain its existence. Companies are required to continue to develop innovation, improve performance, and expand their businesses to continue to survive in the competition.

According to Khaliq et al. (2014) "Financial distress is a situation where a company encounters difficulties or even cannot pay its financial obligations to creditors". Financial distress is important to learn because it serves as a sign that a company will go bankrupt so that anticipatory action can be taken to prevent this.

According to Hanifah (2013) "Another phenomenon of financial distress is the number of companies that tend to experience liquidity problems, which is indicated by the decline in the company's ability to meet its obligations to

\footnotetext{
* Corresponding author.

E-mail address: mubarrokkhusni@gmail.com (Muhammad Khusni Mubarrok)
} 
creditors". One of the things that affects financial distress is financial ratios. Financial indicator variables that are used to predict financial distress are leverage ratios, liquidity ratios, activity ratios, and profitability ratios because these ratios are considered to be able to show financial performance and company efficiency in general to predict the occurrence of financial distress.

Seeing the importance of financial distress for internal and external parties of the company as well as the latest research on financial distress for more actual information in making decisions for the parties, a study will be conducted under the title "Predictions of Financial Distress in Consumers' Goods Industry Companies Listed on the Indonesia Stock Exchange at 2016-2018".

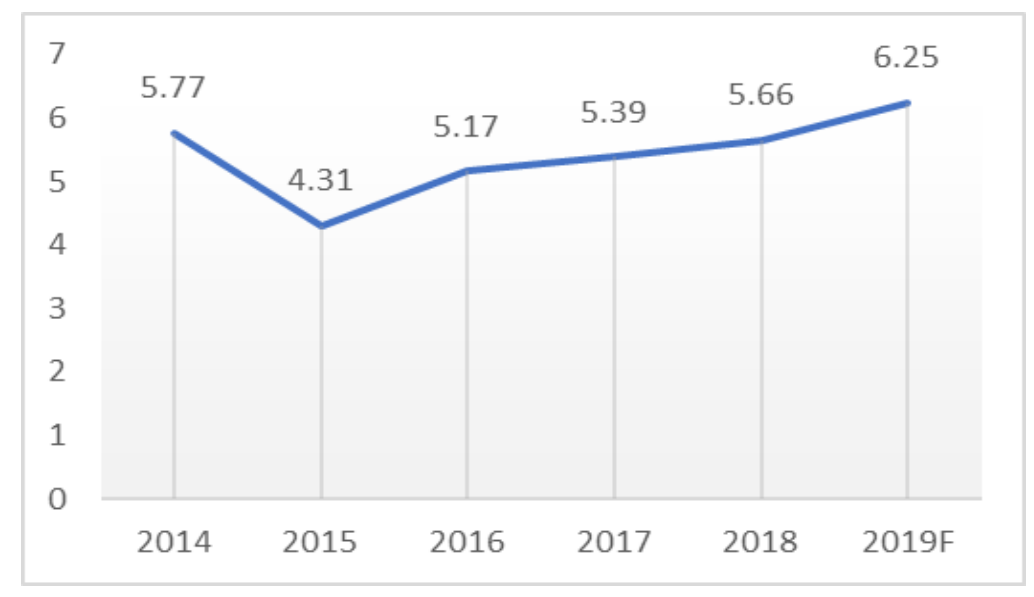

Figure 1. GDP Growth in the Consumer Goods Industry Sector 2019 In (\%) Resource : BPS, Kemenko Perekonomian, 2019

\section{Literature Theory}

\subsection{Financial Distress}

The company's financial condition is a concern for many parties, not only from internal parties such as company management, but from external parties as well as investors, creditors, and other parties. So company management must maintain financial conditions so as not to experience financial distress.

Financial distress is a condition where the company is facing financial difficulties, namely the company's operating cash flow is unable to pay off current liabilities (trade payables or interest expense) and the company is forced to take corrective action to avoid the threat of bankruptcy / liquidation.

\subsection{Financial Ratio}

Financial ratio or financial ratio is a company's financial analysis tool that functions to assess the performance of a company based on comparison of financial data contained in the financial statement post (statement of financial position, income statement, and statement of cash flows).

Hanifah (2013) Financial indicator variables used to predict financial distress are leverage ratios, liquidity ratios, activity ratios, and profitability ratios because these ratios are considered to be able to show financial performance and company efficiency in general to predict financial distress. In general, financial ratios can be classified into four types, including: 


\section{a. Leverage Ratio}

According to Fahmi (2013) leverage ratio is: the ratio used to measure the extent to which a company's assets are financed by debt. The use of debt that is too high will endanger the company because the company will fall into the category of extreme leverage (extreme debt), which is that the company is trapped in high debt and is difficult to release the debt burden.

As in this study the leverage ratio is measured using DAR, Debt to Asset Ratio (DAR) is the ratio used to indicate how much companies use debt in financing the amount of assets or assets Horned and Jhon (2012). The DAR formula is as follows:

$$
\text { DAR }=\frac{\text { Total liabilities }}{\text { Total asset }}
$$

\section{b. Liquidity Ratio}

According to Syafri (2013), "Liquidity illustrates a company's ability to settle short-term obligations". As stated earlier that liquidity is one of the factors that is very influential in determining the success or failure of a company. Liquidity Ratio, shows the company's ability to meet short-term financial obligations. According to Munawir (2010), the definition of a liquidity ratio is:

Liquidity ratios are ratios used to analyze and interpret short-term financial positions, but also greatly help management to check the efficiency of working capital used in the company, also important for long-term creditors and shareholders who ultimately or at least want to know the prospects of dividends and interest payments in the future.

According to Munawir (2010), the liquidity ratio consists of:
a. Current Ratio
b. Cash ratio
c. Acid test ratio
d. Working capital to assets ratio

As in this study Liquidity ratios are measured using Current Ratio, Current Ratio according to Sutrisno (2016) is a ratio that compares current assets owned by companies with short-term debt. Assets here include cash, trade receivables, stock securities and other current assets. While short-term debt includes trade debt, notes payable, bank loans, salary debts, and other debts that must be paid immediately.

The Current Ratio formula is as follows:

$$
\mathrm{CR}=\frac{\text { Current Asset }}{\text { Current Liabilities }}
$$

\section{c. Activity Ratio}

According to Atika et al. (2012) "This ratio, which is often known as the rotation ratio and also the operating capacity ratio, is a ratio used to measure a company's ability to manage its assets".

As in this study the Activity ratio is measured using Total Asset Turnover (TATO). "Total Asset Turnover measures the extent of a company's ability to generate sales based on the total assets owned by the company," according to Hanafi (2009). 
The TATO formula is as follows:

$$
\text { TATO }=\frac{\text { Net sales }}{\text { Total asset }}
$$

\section{d. Profitability ratio}

Profitability ratio is a ratio that aims to see the company's ability to generate profits. According to Widarjo and Setiawan Doddy (2009) states that: profitability shows the efficiency and effectiveness of the use of company assets because this ratio measures the ability of companies to generate profits based on the use of assets. With the effectiveness of the use of company assets will reduce costs incurred by the company, the company will get savings and will have sufficient funds to run its business. With the adequacy of these funds, the possibility of companies experiencing financial distress will be smaller.

As in this study the profitability ratio is measured using Return On Assets (ROA). namely measuring the effectiveness of the company in generating profits by utilizing its assets (Ang, 1997 in Hanifah, 2013). According to Ardiyanto (2011) If return on assets (ROA) increases, it means that the company's sales level will increase and eventually will also increase the level of profitability that can be enjoyed by shareholders. The ROA formula is as follows:

$$
\mathrm{ROA}=\frac{\text { Net profit }}{\text { Total asset }}
$$

\section{Theoritical Framework}

\subsection{Leverage Ratio to Financial Distress}

Leverage ratio analysis is needed to measure the company's ability to pay off its obligations (both short-term and long-term). As in this study the leverage ratio is measured using the total debt to asset ratio (DAR). Debt to asset ratio (DAR) is the ratio used to measure the portion of assets used to guarantee the overall liabilities or debts that a company has. Research conducted by Alifiah, et al (2012), in which his research stated that leverage ratios measured using debt ratios actually have a negative relationship with the opportunity for companies to experience financial distress.

\subsection{Liquidity Ratio to Financial Distress}

Liquidity ratios indicate the ability of a company to meet its financial obligations that must be fulfilled immediately, or the company's ability to meet its financial obligations when billed. The prediction of financial distress itself can be done using financial ratios. The liquidity ratio is one of financial ratios. In this study, liquidity ratios are proxy by current ratio (CR), i.e. current assets divided by current liabilities. Research conducted by Hanifah (2013) where the results of the study stated that the liquidity ratio does not significantly influence the likelihood of financial distress in a company.

\subsection{Activity Ratio to Financial Distress}

Activity ratio is a ratio that measures a company's ability to manage its assets for the company's operations. Financial distress can be predicted using financial ratios. One of the financial ratios is the activity ratio. As in this study the activity ratio is measured using the total asset turnover ratio (TATO). Total asset turnover ratio (TATO) is used to measure the ability of funds that are embedded in the whole assets that revolve in a period or the ability of capital invested to generate income. Research by Alifiah, et al (2012) states that the activity ratio proxied by total asset turnover ratio (TATO) is negatively related and significant in influencing the chances of financial distress in a company. This is reinforced by research conducted by Hanifah (2013) which states 44 that the ratio of operating 
capacity measured by using the total asset turnover ratio (TATO) also has a significant negative effect on the likelihood of financial distress.

\subsection{Profitability Ratio to Financial Distress}

Positive profitability indicates that the company has succeeded in marketing its products, so that it will increase sales and ultimately will also increase profits earned by the company. Financial ratios can be used to predict financial distress. One of the financial ratios is the profitability ratio. The research uses return on assets (ROA) in measuring profitability ratios. In a study conducted by Kristijadi \& Almilia (2003) stated that "significant profit margins have a negative effect on financial 45 distress, which means that the higher the profits earned by a company, the smaller a company will experience financial distress".

Based on the description above, a research model can be made as shown in Figure 2.

To illustrate the relationship of the independent variable, in this case is the leverage ratio, liquidity ratio, activity ratio, and profitability ratio to the dependent variable financial distress. The framework for describing the relationship is as follows:

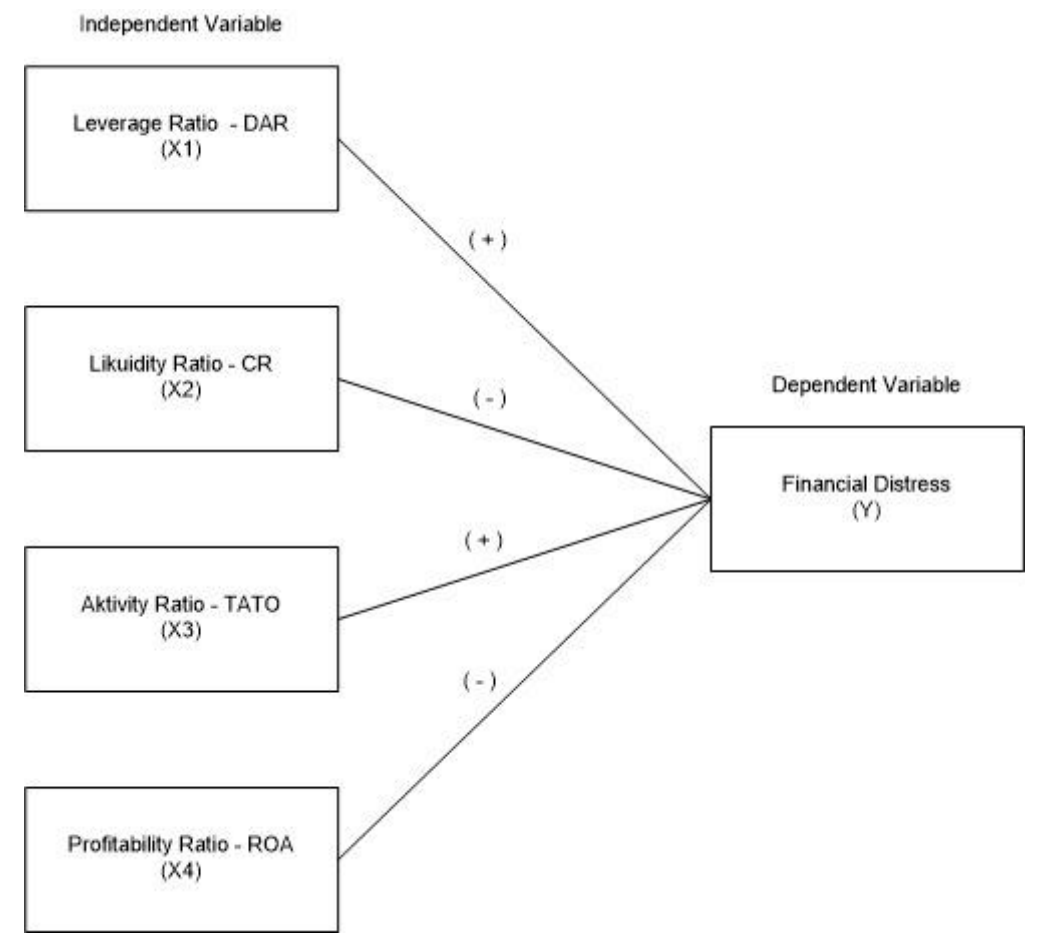

Figure 2 Research model (in Indonesia)

\section{Hypotheses}

According to Dantes (2012), a hypothesis that is a presumption or assumption that must be tested through data or facts obtained through research.

Based on the description of the empirical review, theoretical review and mindset above, the authors propose the following hypothesis: 
H1 = Leverage Ratio has a positive effect on the prediction of financial distress in a company.

$\mathrm{H} 2$ = Liquidity Ratio has a negative effect on the prediction of financial distress in a company.

$\mathrm{H} 3$ = Activity Ratio has a negative effect on the prediction of financial distress in a company.

$\mathrm{H} 4$ = Profitability Ratio has a negative effect on the prediction of financial distress in a company.

\section{Research Method}

\subsection{Research Variable}

The dependent variable in this study is financial distress. The independent variable used is financial ratios consisting of leverage ratios measured using the total debt to assets ratio (DAR), liquidity ratios measured by the current ratio (CR), activity ratios measured by total assets turnover ratio (TATO), and the last is profitability ratios measured using return to assets (ROA).

\subsection{Sample Determination}

In this study, the population used is the Consumer Goods Industry company listed on the Indonesia Stock Exchange in 2016-2018. The sample selection technique used in this study was purposive sampling. Based on the sampling results obtained by mining companies there are 54 companies and those who meet the sampling criteria are 7 companies. The analysis will be carried out over 3 periods, namely the period 2016-2018 so that the data from the sample amounted to 7 × $3=32$.

\subsection{Data Analysis Technique}

The data analysis technique used in this study is logistic regression analysis. According to Gujarati (2012) the logistic regression model can be written as follows:

$$
L i=\mathrm{I}_{\mathrm{n}}\left(\frac{P_{i}}{1-P_{i}}\right)=\beta_{0}+\beta_{1} X_{1}
$$

Based on the logistic regression model, the logistic regression model in this study is as follows:

$$
L_{i}=l_{n}\left(\frac{P_{i}}{1-P_{i}}\right)=\beta_{0}+\beta_{1} D A R+\beta_{2} C R+\beta_{a} \text { TATO }+\beta_{4} R O A
$$

$$
\text { Information: }
$$

$\mathrm{P} \quad=$ the probability of occurrence of the dependent variable $(\mathrm{Y})$

$\mathrm{P}=1$; Companies that experience financial distress.

$\mathrm{P}=0$; Companies that do not experience financial distress.

B0 = Constant

$\beta 1=$ DAR coefficient

$\beta 2=$ CR coefficient

$\beta 3=$ TATO coefficient

$\beta 4 \quad=$ ROA coefficient

DAR = Debt to Asset Ratio

$\mathrm{CR}=$ Current Asset

TATO $=$ Total Asset Turnover

ROA $=$ Return on Assets 


\section{Result and Discussion}

\subsection{Descriptive Statistical Analysis}

Descriptive statistics is the process of collecting, summarizing, and presenting data that is used to describe data in general and adequately. To see an overview of the data used in research can be seen in the following table:

Table 1 Company Data Statistics

\begin{tabular}{lcccc}
\hline Ratio & $\mathrm{N}$ & Minimum & Maximum & Mean \\
DAR & 33 & 0.080 & 0.726 & 0.39782 \\
CR & 33 & 0.748 & 8.638 & 2.91587 \\
TATO & 33 & 0.060 & 3.105 & 1.10814 \\
ROA & 33 & -0.176 & 0.921 & 0.10627 \\
\hline
\end{tabular}

The general description of descriptive statistics of the independent variables that have been shown in table 4 can be explained as follows:

\section{a. Debt Asset To Ratio (DAR)}

Debt Asset To Ratio (DAR) has the lowest value of 0.080 and the highest value of 0.726 . The descriptive statistics table above shows the average Debt Asset To Ratio (DAR) of 0.397 and the standard deviation value of 0.176. The average value (mean) is greater than the standard deviation of 0.397>0.176, meaning that the distribution of Debt Asset To Ratio (DAR) data has no gaps and the mean value can be used as a representation of the whole data.

\section{b. Current Ratio (CR)}

Current Ratio (CR) has the lowest value of 0.748 and the highest value of 8.638. The descriptive statistics table above shows the average Debt Asset To Ratio (DAR) of 2.915 and the standard deviation value of 1.974. The average value (mean) is greater than the standard deviation of 2.915> 1.974, meaning that the distribution of Debt Asset To Ratio (DAR) data has no gaps and the mean value can be used as a representation of the whole data.

\section{c. Total Asset Turnover (TATO)}

Total Asset Turnover (TATO) has the lowest value of 0.060 and the highest value of 3.105. The descriptive statistics table above shows the average Total Asset Turnover (TATO) of 1.108 and the standard deviation value of 0.648. The mean value is greater than the standard deviation of 2.915> 1.974, meaning that the Total Asset Turnover (TATO) data distribution has no gaps and the mean value can be used as a representation of the whole data.

\section{d. Return On Asset (ROA)}

Return On Assets (ROA) has the lowest value -1.76 and the highest value 0.921. Figure 2 Descriptive statistics table above shows the average Return on Assets (ROA) of 0.106 and the standard deviation value of 0.197 , meaning that the distribution of Return On Assets (ROA) data does not have gaps and the mean value can be used as a representation of the whole data.

\subsection{Multikolinearitas test result}

Multicollinearity test is performed to determine whether there is a correlation between the independent variables in the regression model. A good regression model does not have a regression between independent variables. Statistical 
identification to describe the symptoms of multicollinearity can be done by looking at the value of tolerance and Variance Inflation Factor (VIF). Gozali (2007) states that the data is declared free of multicollinearity problems if it has a tolerance value $>0.10$ or equal to VIF value $<10$. The following is a table of multicollinearity test results:

Table 2 Multikolinearitas Test Result

\begin{tabular}{lccc}
\hline Ratio & Tolerance & VIF & Result \\
DAR & 0.927 & 1.081 & No multicollinearity \\
CR & 0.551 & 1.814 & No multicollinearity \\
TATO & 0.648 & 1.543 & No multicollinearity \\
ROA & 0.924 & 1.083 & No multicollinearity \\
\hline
\end{tabular}

Based on the multicollinearity test results in table 6 , the variance value shows that there are no independent variables that have a tolerance value $<0.10$ and there is no VIF value $>10$. It can be concluded that the regression model in this study does not occur symptom of multicollinearity. Therefore a regression model is feasible to use.

\subsection{Logistics Regression Test Result}

a. Hosmer and Lemeshow's Testing Results goodness of fit

To assess the feasibility of the regression model in predicting the use of the Chi Square Hosmer and Lemeshow Test, this test is used to test the hypothesis:

H0: There is a difference between the predicted classification and the observed classification.

Ha: There is no difference between the predicted classification and the observed classification. The following are the results of the Hosmer and Lemeshow's goodness of fit test:

Table 3 Hosmer and Lemeshow Test

\begin{tabular}{lccc}
\hline Step & Chi-Square & Sig. & Result \\
\hline 1 & 8,983 & 0,344 & Model suitable \\
\hline
\end{tabular}

Based on the test results in table 7 shows the Chi Square value of 8.983 with a significance value of 0.344 . From these results it can be seen that the Significance value> 0.05 means that H0 is accepted that there is no difference between the predicted classification and the observed classification. Thus, this regression model can be used for further analysis.

\section{b. Log Likelihood Value Test Results (value -2 Log Likelihood Value)}

To see a better model for predicting financial distress, you can use -2 Log likelihood. The results of the -2 Loglikelihood calculation in the first block (block number $=0$ ) show the value of -2 Loglikelihood of 58.224 as shown in table 4.

Table 4 Log Likelihood Value Test Results (block number $=0$ )

\begin{tabular}{ccc}
\hline Iteration & -2 Log Likelihood & Coefficients Constant \\
\hline Step 0 & 105.689 & -1.200 \\
\hline
\end{tabular}


Then the results of the calculation of the value of $\log 2$ Loglikelihood in the second block (block number $=1$ ) shows the value of $-2 \operatorname{Loglikelihood~equal~to~a~decrease~in~the~second~block~(block~number~}=1$ ) shown in table 9 as follows:

Table 5 Log Likelihood Value Test Results (block number $=1$ )

\begin{tabular}{cccccccc}
\hline \multicolumn{2}{c}{ Iteration } & -2 Log Likelihood & Coefficients Constant & DAR & CR & TATO & ROA \\
\hline Step 1 & 1 & 90.181 & -1.205 & .996 & -.133 & .158 & -2.511 \\
& 2 & 79.539 & -1.745 & 1.792 & -.223 & .498 & -6.301 \\
& 3 & 72.776 & -2.535 & 2.594 & -.253 & 1.160 & -12.941 \\
& 4 & 57.452 & -1.517 & 1.201 & -.306 & 1.035 & -19.731 \\
& 5 & 32.384 & .623 & -1.900 & -.216 & .535 & -41.608 \\
& 20.939 & 1.255 & -3.351 & -.268 & .834 & -70.747 \\
& 7 & 14.482 & 2.636 & -6.090 & -.449 & 1.233 & -108.813 \\
& 11.177 & 4.483 & -9.393 & -.689 & 1.493 & -155.017 \\
9 & 9.821 & 6.279 & -12.295 & -.904 & 1.440 & -202.458 \\
& 9.458 & 7.767 & -14.603 & -1.076 & 1.304 & -240.762 \\
10 & 9.425 & 8.416 & -15.631 & -1.153 & 1.263 & -257.126 \\
11 & 9.424 & 8.497 & -15.763 & -1.163 & 1.261 & -259.119 \\
12 & 9.424 & 8.498 & -15.765 & -1.163 & 1.261 & -259.144 \\
13 & 9.424 & 8.498 & -15.765 & -1.163 & 1.261 & -259.144 \\
\hline 14 & & & & &
\end{tabular}

The overall evaluation of the regression model uses the value of -2 Loglikelihood, if there is a decrease in the second block compared to the first block, it can be concluded that the second regression model is better, as shown in table 8 and table 9 in the first block (block number $=0$ ) values - 2 Loglikelihood is 105,689 and in the second block (block number =1) -2 Loglikelihood is 90,181 . These results can conclude that the second regression model is better for predicting financial distress.

c. Cox and Snell R Square and Nagelkerke R Square Test Results

The Cox \& Snell R Square and Nagelkerke R Square coefficients in the summary table can be interpreted the same as the coefficient of determination R2 in multiple linear regression.

Table 6 Cox and Snell R Square and Nagelkerke R Square Test Results

\begin{tabular}{cccc}
\hline \multicolumn{3}{c}{ Model Summary } \\
\hline Step & -2 Log likelihood & Cox \& Snell R Square & Nagelkerke R Square \\
1 & $9.424^{\mathrm{a}}$ & .598 & .945 \\
\hline
\end{tabular}

The Nagelkerke R Square coefficient in the Summary model table is a modification of the Cox \& Snell R Square coefficient so that the maximum value can reach one and has a range between 0 and the same as the coefficient of determination R2 in multiple linear regression. As seen in table 10, the Nagelkerke R Square coefficient value is 0.945, which means the ability of the variable ratio of Debt To Asset Ratio, Current Asset, Total Asset Turnover and Return On Asset explains the financial distress prediction variable of $94.5 \%$. The remaining $5.5 \%$ is another factor outside the model that explains the dependent variable.

d. The accuracy of classification predictions

To see the accuracy of the predicted classification predictions can be seen in the table 7 . 
Table 7 The accuracy of calssification predictions

\begin{tabular}{cccc}
\hline Predicted & Non Financial Distress & Financial Distress & Percentage Correct \\
\hline Non Financial Distress & 26 & 0 & 100.0 \\
Financial Distress & 0 & 7 & 100.0 \\
\hline
\end{tabular}

Based on the Classification Table above, there are 26 companies experiencing financial distress. Samples that did not experience financial distress as many as 7 . The table above gives an overall percentage value of $(26+7) / 33=100 \%$ which means the accuracy of this research model is $100 \%$.

\subsection{Hypothesis Test Result}

Hypothesis Testing Results After obtaining a suitable model for the data, then the hypothesis test is then performed. Hypothesis testing is done to answer the problem formulation in this study. Following are the results of testing the hypothesis in this study:

\begin{tabular}{lcccc}
\multicolumn{5}{c}{ Table 8 Hypothesis test result } \\
\hline Ratio & B & Wald & Sig. & Ha \\
\hline DAR & -15.765 & 2.599 & 0.107 & Reject \\
CR & -1.163 & 1.600 & 0.206 & Reject \\
TATO & 1.261 & 0.295 & 0.587 & Reject \\
ROA & -259.144 & 5.951 & 0.015 & Accept \\
\hline
\end{tabular}

Based on table 13, the effect of Debt To Asset Ratio (DAR) ratio, Current Ratio (CR), Total Asset Turnover (TATO), and Return On Asset (ROA) can be explained as follows:

\section{a. Debt To Asset Ratio (DAR)}

Ho: $\beta 1 \leq 0$, meaning that the Debt To Asset Ratio (DAR) ratio does not positively influence financial distress in the Consumer Goods Industry companies listed on the Indonesia Stock Exchange for the period of 2016-2018.

Ha: $\beta 1 \leq 0$, meaning that the ratio of Debt to Asset Ratio (DAR) has a positive effect on financial distress in the Consumer Goods Industry companies listed on the Indonesia Stock Exchange for the period 2016-2018.

Based on table 12 it can be seen that the Debt To Asset Ratio (DAR) ratio variable has a coefficient of -15,675 with a significance level greater than the specified significance value of $0.107<0.05$. This shows that the Debt To Asset Ratio (DAR) variable has no positive effect on the financial distress (Y) of the Consumer Goods Industry companies listed on the Indonesia Stock Exchange for the period of 2016-2018. Thus Ho was rejected.

\section{b. Current Ratio (CR)}

Ho: $\beta 1 \leq 0$, meaning that the Current Ratio (CR) ratio has no negative effect on financial distress in the Consumer Goods Industry companies listed on the Indonesia Stock Exchange for the period of 2016-2018.

Ha: $\beta 1 \leq 0$, meaning that the ratio of Current Ratio (CR) negatively affects financial distress in the Consumer Goods Industry companies listed on the Indonesia Stock Exchange for the period of 2016-2018.

Based on table 12 it can be seen that the variable ratio Current Ratio (CR) has a coefficient of $-1,163$ with a significance level greater than the specified significance value of $0.206<0.05$. This shows that the Current ratio $(\mathrm{CR})$ 
variable has a negative but not significant effect on the financial distress (Y) of the Consumer Goods Industry companies listed on the Indonesia Stock Exchange for the period of 2016-2018. Thus Ho was rejected.

\section{c. Total Asset Turnover Ratio (TATO)}

Ho: $\beta 3 \leq 0$ means that the ratio of Total Asset Turnover (TATO) ratio does not negatively affect financial distress in the Consumer Goods Industry companies listed on the Indonesia Stock Exchange for the period of 2016-2018.

Ha: $\beta 3 \leq 0$ means that the ratio of the Total Asset Turnover Ratio (TATO) has a negative effect on financial distress in the Consumer Goods Industry companies listed on the Indonesia Stock Exchange for the period of 2016-2018.

Based on table 12 it can be seen that the Total Asset Turnover (TATO) variable has a coefficient of 1.261 with a significance level greater than the specified significance value of $1.261<0.05$. This shows that the Total Asset Turnover Ratio (TATO) variable has a negative but not significant effect on the financial distress (Y) of the Consumer Goods Industry companies listed on the Indonesia Stock Exchange for the period 2011-2015. Thus Ho was rejected.

\section{d. Return on Asset (ROA)}

Ho: $\beta 4 \geq 0$, meaning that Return on Asset (ROA) Ratio does not negatively affect financial distress in the Consumer Goods Industry companies listed on the Indonesia Stock Exchange for the period of 2016-2018.

Ha: $\beta 4 \leq 0$, meaning Return on Assets (ROA) Ratio has a negative effect on financial distress in the Consumer Goods Industry companies listed on the Indonesia Stock Exchange for the period of 2016-2018.

Based on table 12 it can be seen that the Return On Asset (ROA) ratio variable has a coefficient of $-259,144$ with a significance level smaller than the specified significance value of $-259,144<0.05$. This shows that the Return On Asset (ROA) variable has a negative and significant effect on the company's financial distress (Y) of the Consumer Goods Industry which is listed on the Indonesia Stock Exchange for the period of 2016-2018. Thus Ho was accepted.

\section{Conclusion}

This study aims to test and prove and find out how much influence the Debt Asset To Ratio (DAR), Current Ratio (CR), Total Asset Turnover (TATO), and Return On Assets (ROA) on financial distress in the Consumer Goods Industry company on the Stock Exchange The effects of Indonesia with the study year 2016 to 2018. Then based on the results of the logistic regression this study can draw conclusions:

1. Debt Asset To Ratio (DAR) has no positive effect on Financial Distress (Rejected)

2. Current Ratio (CR) has a negative but not significant effect on Financial Distress (Rejected)

3. Total Asset Turnover (TATO) has no negative effect on Financial Distress (Rejected)

4. Return on Assets (ROA) has a negative and significant effect on Financial Distress (Accepted)

\section{References}

Ardiyanto, F. D. (2011). Prediksi Rasio Keuangan Terhadap Financial Distress Perusahaan Manufaktur yang Terdaftar di BEI Periode 2005-2009. Universitas Diponegoro Semarang.

Asset, M. (2018). Pertumbuhan Industri Barang Konsumsi Dinilai Melambat. https://www.cnbcindonesia.com/market/20181019191302-17-38252/pertumbuhan-industri-barang-konsumsidinilai-melambat

Atika, Darminto, \& Hindayani, Si. R. (2012). Pengaruh Beberapa Rasio Keuangan terhadap Prediksi Kondisi Financial Distress.

Hanifah, O. E. (2013). Pengaruh Struktur Corporate Governance dan Financial Indicators Terhadap Kondisi 
Financial Distress.

Hidayat, M. A., \& Meiranto, W. (2014). Prediksi Financial Distress Perusahaan Manufaktur di Indonesia. DIPONEGORO JOURNAL OF ACCOUNTING, 3,1 .

Khaliq, A., Altarturi, B. H. M., Thaker, H. M. T., Harun, M. Y., \& Nahar, N. (2014). Identifying Fin ancial Distress Firms: A Case Study of Malaysia's Government Linked Companies (GLC). International Journal of Economics, Finance and Management, 141.

Kristijadi, \& Almilia, L. S. (2003). Analisis Rasio Keuangan Untuk Memprediksi Kondisi Financial DIstress Perusahaan Manufaktur yang Terdapat di Bursa Efek Indonesia. JAAI, 7.

Pranowo, K., Noer, A. A., \& Adler, H. M. (2010). Determinant of Corporate Financial Distress in an Emerging Market Economy: An Empirical Evidence from the Indonesian Stock Exchange 2004-2008. Journal of Finance and Economics.

Widarjo, W., \& Setiawan Doddy. (2009). Pengaruh Rasio Keuangan Terhadap Financial Distress Perusahaan Otomotif. JURNAL BISNIS DAN AKUNTANSI, 11, 111. 